\title{
Evaluation of the hygienic and sanitary quality of attiéké produced by hand in Burkina Faso: case of "Burkina journalier", a local processing unit in Dedougou
}

\author{
René Dembélée ${ }^{1,2}$, Ali Konaté ${ }^{1}$, Oumar Traoré ${ }^{1,2}$, Kaboré W. A. Désiré ${ }^{1}$, Luc Sarambé ${ }^{2}$ Charles Edouard T. Kaboré ${ }^{3}$, \\ Harouna Bidiga ${ }^{4}$, Alfred S. Traoré ${ }^{1}$ and Nicolas Barro ${ }^{1}$

\begin{abstract}
${ }^{1}$ Laboratoire de Biologie Moléculaire, d'Épidémiologie et de Surveillance des Bactéries et Virus Transmissibles par les Aliments/ Centre de Recherche en Sciences Biologiques, Alimentaires et Nutritionnelles (CRSBAN)/Université Ouaga I Pr Joseph KI-ZERBO, 03 BP 7021 Ouagadougou 03, Burkina Faso ${ }^{2}$ Unité de Formation et de Recherche en Sciences Appliquées et Technologiques (UFR/SAT)/Université de Dédougou, BP 07 Dédougou Burkina Faso ${ }^{3}$ Projet sur la Résilience des Populations pauvres et très pauvres, et sécurité alimentaire dans la boucle du Mouhoun (REPAM)/Groupe de Recherche et d'Échange Technologique (GRET), 10 BP 810 Ouagadougou 10 Burkina Faso

${ }^{4}$ Laboratoire du Lycée Professionnel Régional Nazi BONI (LPRNB) de Dédougou, Burkina Faso
\end{abstract}

Received 05 July 2018, Accepted 08 Sept 2018, Available online 11 Sept 2018, Vol.6 (Sept/Oct 2018 issue)

\begin{abstract}
In Burkina Faso, the lack of good hygienic practices (GHP) by producers and the uncontrolled sale of attiéké expose consumers to health risks like the Toxi-Infections Food (TIF). Our study aims to establish the hygienic quality of attiéké produced at Dédougou (Boucle du Mouhoun) and how to apply good manufacturing practices (GMP) and good hygiene practices (GHP) improving this attiéké. Two samples of attiéké were collected for analysis of which tasting test by 24 tasters (men and women) on characteristics such as color, flavor, appearance (fibres), texture, moisture, granulometry and hardness; measurement of $\mathrm{pH}$, determination of acidity, humidity, ash content, enumeration of bacteria, yeasts and molds were also done according to the recommanded methods. For both samples, our study showed 3.6, 0.85 and $1.9,49.13$ and 53.5, 0.82 respectively for $\mathrm{pH}$, acidity, moister content and ash content. Humidity levels were $49.13 \pm 0.02$ and $53.5 \pm 0.05$ respectively for sample 1 and sample 2. Total aerobic mesophil flora of $3.73 .10^{4} \mathrm{cfu} / \mathrm{g}$ and $4.52 .10^{4}$ $\mathrm{cfu} / \mathrm{g}$, total coliforms rate $\leq 15 \mathrm{cfu} / \mathrm{g}$ and yeasts and molds value ranging from $3.1 .10^{3}$ to $4.2 .10^{3} \mathrm{cfu} / \mathrm{g}$ were observed. Special attention should be given to the following: transmission of fecal germs; handling of attiéké after cooking and equipments used for serving; and hand washing and environmental hygiene.
\end{abstract}

Keywords: Attiéké, quality, improvement, manufacturing practices, hygiene practices.

\section{Introduction}

Cassava (Manihot esculenta CRANTZ) is an important root crop in Africa, Asia, South America and India, providing energy for about 500 million people (Padmaja and Steinkraus, 1995). Traditionally, cassava roots are processed by different methods varying from region to region, leading to many different products like "gari", "tapioca", "placali" and "attiéké". Among the products derived from cassava, attiéké seems to be the most demanded and most consumed at the level of large and medium-sized cities in Burkina (Diancoumba, 2008). It is an essentially flavour starchy food, produced from fermented cassava dough and starch is known to be very

Corresponding author: René Dembélé (ORCID ID: 0000-0002-9282 8555), Laboratoire de Biologie Moléculaire, d’Épidémiologie et de Surveillance des Bactéries et Virus Transmissibles par les Aliments (LaBESTA)/Centre de Recherche en Sciences Biologiques, Alimentaires et Nutritionnelles (CRSBAN)/Université de Dédougou, BP 07 Dédougou, Burkina Faso, Tel : (00226) 70051342

DOI : https://doi.org/10.14741/ijmcr/v.6.5.4 important in body growth because of energy produced. Attiéké is widely consumed in Burkina Faso and its production is incoming generator activity especially for women (Diabcoumba, 2008). People in Burkina Faso enjoy it as a staple food, accompanied with salt, raw onions, spices, oil and fried fish (Guira et al, 2016). Attiéké is produced in a traditional way by producers often grouped in association or cooperative.

However, the lack of good hygienic practices (GHP) by women producers and the uncontrolled sale of attiéké in the street expose consumers to health risks, that is to say, the Toxi-Infections Food (TIF). Otherwise, it's known that food borne illness of microbial origin are a major international health problem associated to food safety and an important cause of death in developing countries (WHO, 2002a ; 2002b). The problems of food safety in the developed countries differ considerably from those of developing countries. Whereas, in developing countries traditional methods of processing and packaging, improper holding temperature, poor personal hygiene of food handlers are still observed during food marketing 
and technology (Barro et al, 2002 ; Mensah et al, 2002). In Burkina Faso, several studies were done concerning the nutritional quality of the "Attiéké" (Bassolé, 2009 ; Guira et al, 2016) but its hygienic quality is poorly understood and unevenly studied. Therefore, the present study aims to establish the hygienic status of Attiéké produced at Dédougou and how to apply good manufacturing practices (GMP) and good hygiene practices (GHP) improving the sector and the products.

\section{Material and methods}

\section{Sampling}

Two samples of Attiéké (AT1 obtained before production scheme improvement and AT2 obtained after improvement) were collected for analysis. The samples were transported to the laboratory on ice and processed within $2 \mathrm{~h}$ after the collection.

\section{Tasting test}

A tasting test was conducted from our two prepared and flavored samples. The panel consisted of 24 tasters, men and women included. A hedonic test made it possible to measure the acceptability of our products by the panelists. Consumer reactions were recorded using a rating scale of technological variables such as color, flavor, appearance (fibres), texture, moisture, granulometry and hardness. Assessment of Good manufacturing practices (GMP) and good hygiene practices (GHP) application was done (ONUDI, 2005).

\section{Measurement of $\mathrm{pH}$ and determination of Acidity}

Ten gram (10 g) of each sample were dissolved in $75 \mathrm{ml}$ of sterile peptoned buffered water and mixed. The $\mathrm{pH}$ was directly measured with a numeric $\mathrm{pH}$-meter (WTW multi line P4). For Total acidity, $10 \mathrm{~g}$ of each sample are mixed with $75 \mathrm{ml}$ of distilled water in an erlenmeyer. Ten $\mathrm{ml}(10$ $\mathrm{ml}$ ) of the dilution were then titrated against $\mathrm{NaOH} 0.1 \mathrm{~N}$ using phenolphthalein as indicator.The total acidity was then calculated as a percentage of lactic acid.

\section{Determination of humidity}

According to the AOAC method (2000), the samples were weighed $\left(P_{0}\right)$ using a SARTORUIS BP $310 \mathrm{~S}$ precision balance (Gottingen, West Germany). They were dried in a brand oven (MEMERT, Schwabach West Germany) at 105 ${ }^{\circ} \mathrm{C}$ for $24 \mathrm{~h}$. At the out let of the oven, the samples were cooled in a desiccator and weighed $\left(P_{1}\right)$; the percentage of humidity $(H)$ has been determined by calculation according to the formula: $\mathrm{H}=\frac{\mathrm{P} 0-\mathrm{P} 1}{\mathrm{P} 0} \times 100$

\section{Determination of ash content}

According to the AOAC method (2000), this content has been determined by mineralization of a sample of $5 \mathrm{~g}\left(\mathrm{P}_{0}\right)$ at $550{ }^{\circ} \mathrm{C}$ for $6 \mathrm{~h}$ in a muffle furnace (NABERTERM, Gmbh LT9/11/B180, Germany), until destruction of all organic matter in the sample. The weighing $\left(\mathrm{P}_{1}\right)$ after cooling in a desiccator of the ash obtained made it possible to determine the ash content according to the formula:

$\%$ ash content $=\frac{\mathrm{P} 0-\mathrm{P} 1}{\mathrm{P} 0} \times 100$

\section{Enumeration of Bacteria, Yeasts and Molds}

In the laboratory, the preparation of samples and tenfold dilutions for inoculation outs agar plates were carried out according to ISO-6887(ISO-6887,1999). For all numerations, $10 \mathrm{~g}$ of the samples were homogenized in a stomacher bags with $90 \mathrm{ml}$ of sterile peptoned buffered water. The Tenfold serials dilution was prepared and spread-plated for microorganisms count. Yeasts and Molds were cultivated on Sabouraud-Chloramphenicol Agar (Oxoid LTD, Basingstore, Hamsphire, England) after incubated at $25^{\circ} \mathrm{C}$ for $4-5$ days and counted according to ISO 7954 standards ISO-7954 (1988). Lactic acid bacteria were cultivated onto Violet Red Bile Lactose (VRBL) agar (Liofilchem, Italy) and incubated anaerobically in an anaerobic conditions (anaerobic jar) at $37^{\circ} \mathrm{C}$, for 2 - 3 days and counted according to ISO 15214 standards ISO15214(1998).

\section{Results}

\section{Hedonic test parameters}

The figures 1 to 7 show the results obtained after performing the tasting test. The different appreciations are given as "low grade", "less good", "good", "very good" and "excellent".

Good manufacturing practices (GMP) and good hygiene practices $(G H P)$ diagnosis

Our findings are recorded in the tables below. Table 1 gives the characteristics of the GMP and GHP concerning the workers staff and table $\mathbf{2}$ is about the same characteristics evaluation in the food environment.

\section{Measures of $\mathrm{pH}$, acidiy, humidity and ash content}

For both samples, the $\mathrm{pH}$ average was $3.6 \pm 0.08$. The acidity ranged from $0.85 \pm 0.02$ to $1.9 \pm 0.07$. In this study, the moister content of attiéké samples varies from 49.13 \pm 0.02 to $53.5 \pm 0.05$ per $100 \mathrm{~g}$ of attiéké. Our analysis showed that the total ash content is $0.82 \pm 0.05$ per $100 \mathrm{~g}$ of attiéké. Humidity levels were $49.13 \pm 0.02$ and $53.5 \pm$ 0.05 (Table 3).

\section{Determination of microbiological parameters}

Our study showed a total aerobic mesophil flora level varied between $3.73 .10^{4}$ and $4.52 .10^{4} \mathrm{cfu} / \mathrm{g}$ while the total coliforms were found at the rate $\leq 15 \mathrm{cfu} / \mathrm{g}$. Yeasts and molds showed value ranging from $3 \cdot 1 \cdot 10^{3}$ to $4 \cdot 2 \cdot 10^{3} \mathrm{cfu} / \mathrm{g}$ (Table 4). 


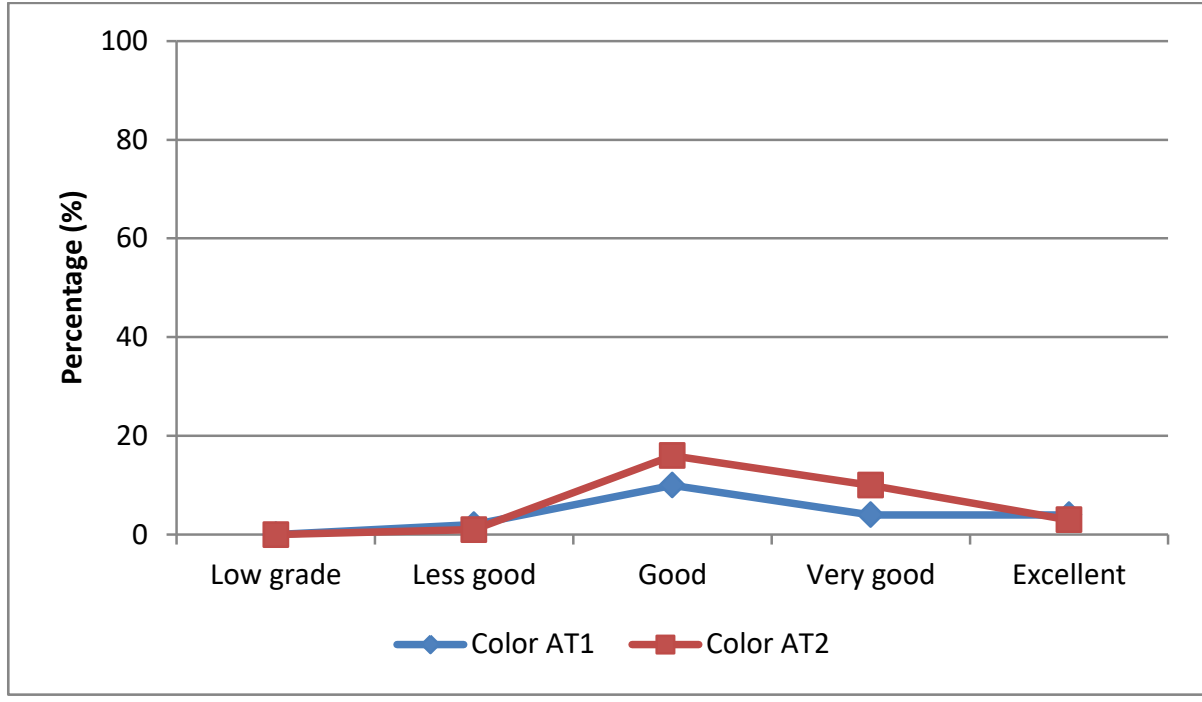

Figure 1. Tasting panel results of color

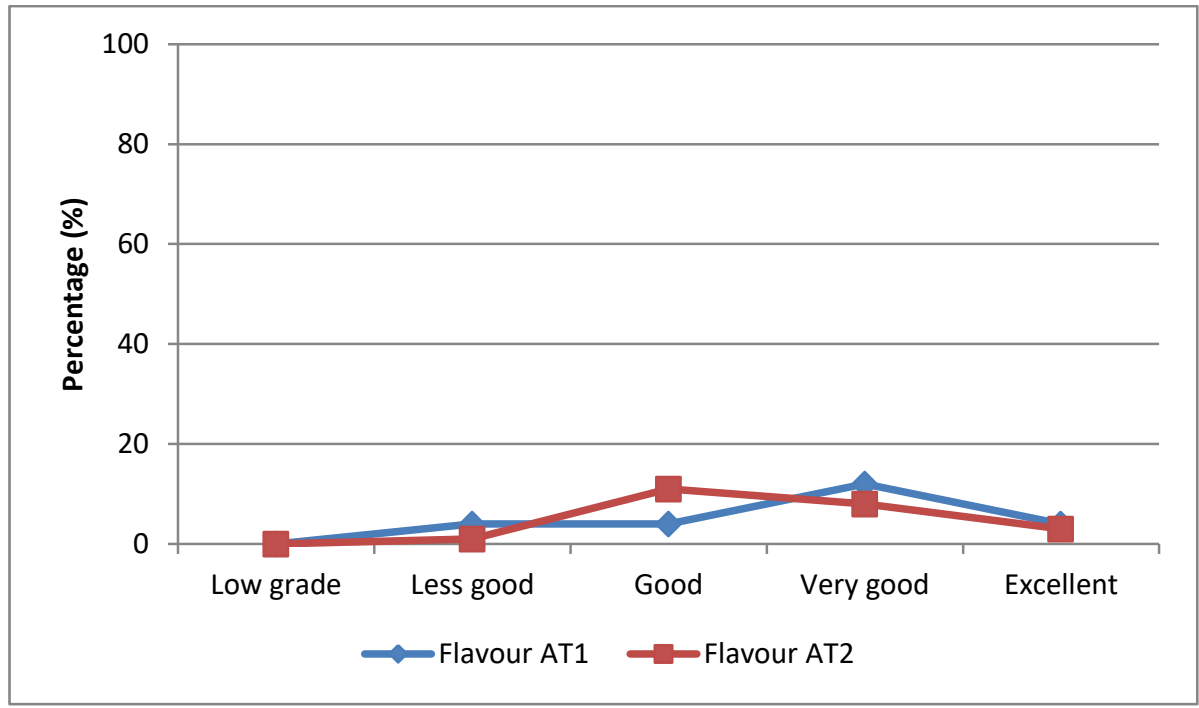

Figure 2. Tasting panel results of flavour

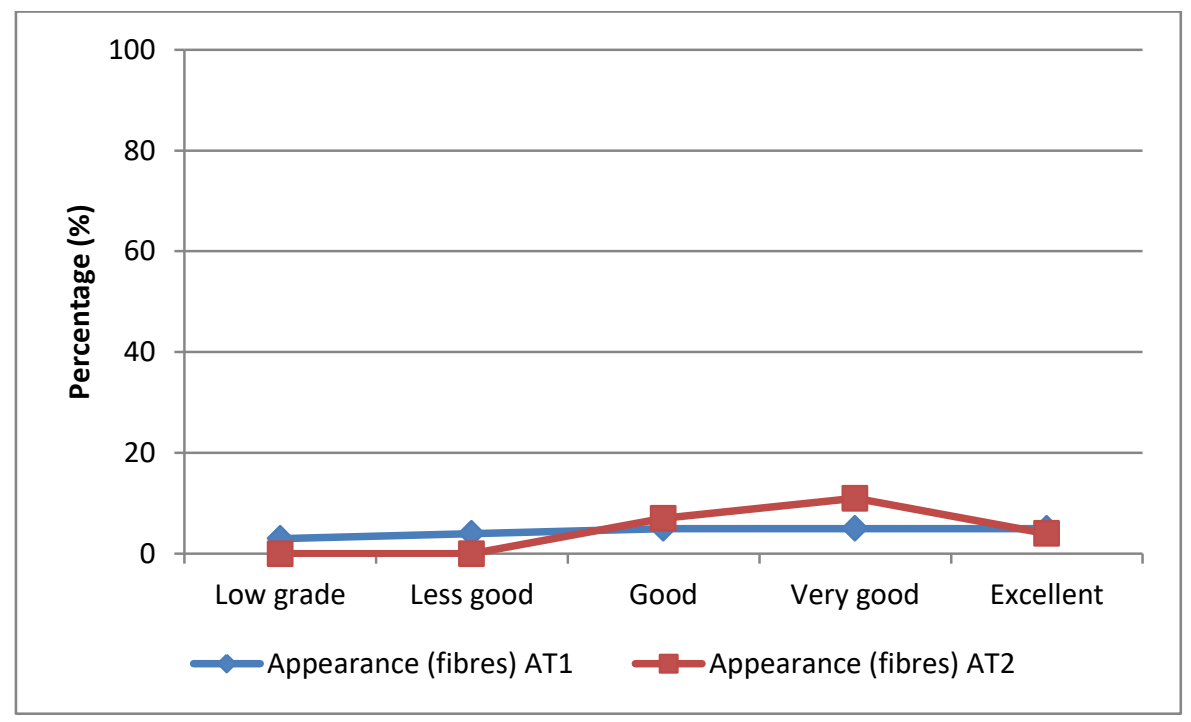

Figure 3. Tasting panel results of appearance

1023 | Int. J. of Multidisciplinary and Current research, Vol.6 (Sept/Oct 2018) 


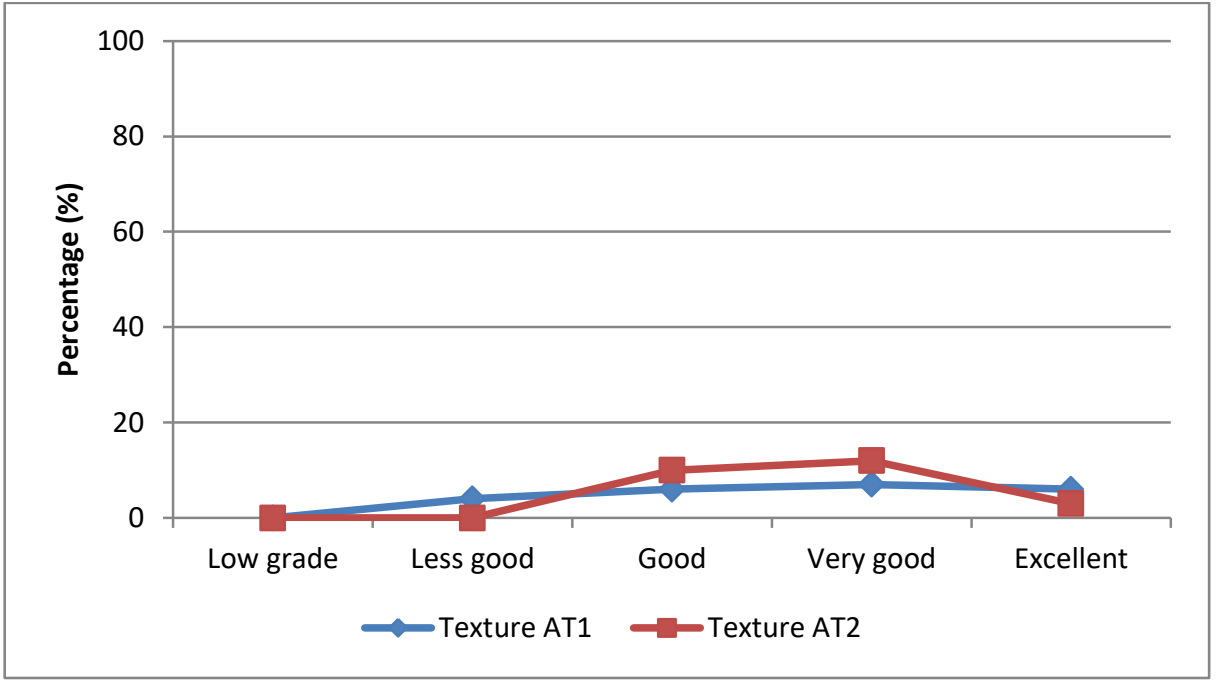

Figure 4. Tasting panel results of texture

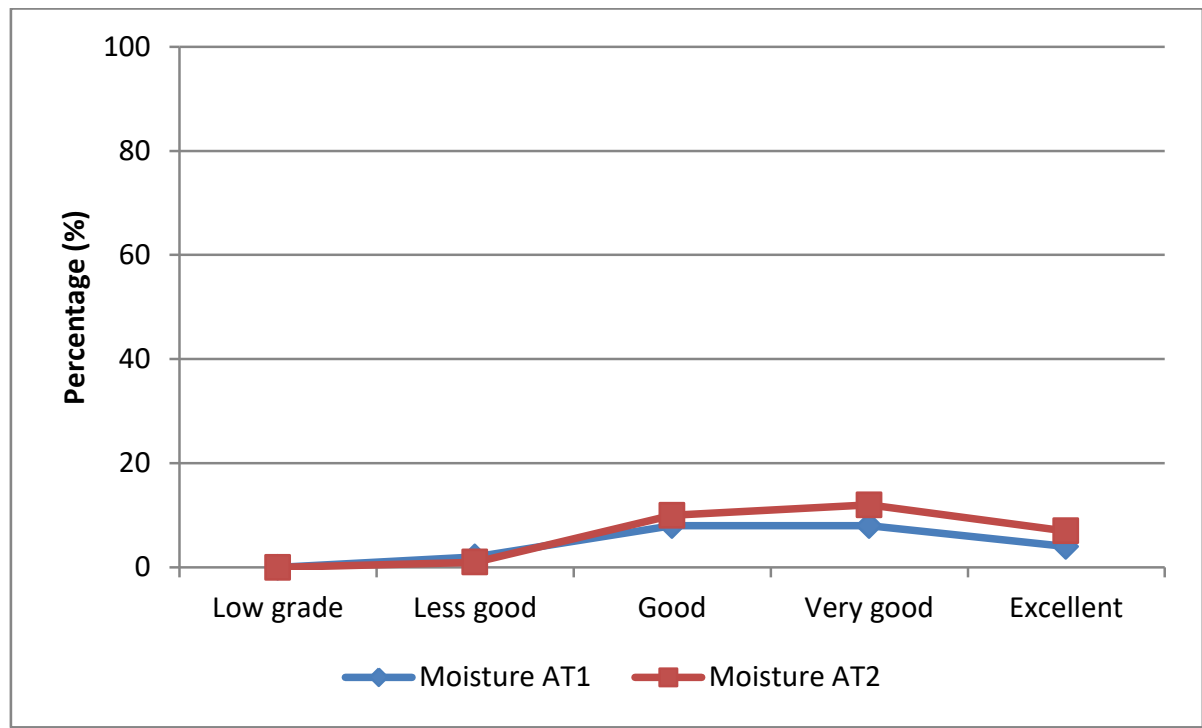

Figure 5. Tasting panel results of moisture

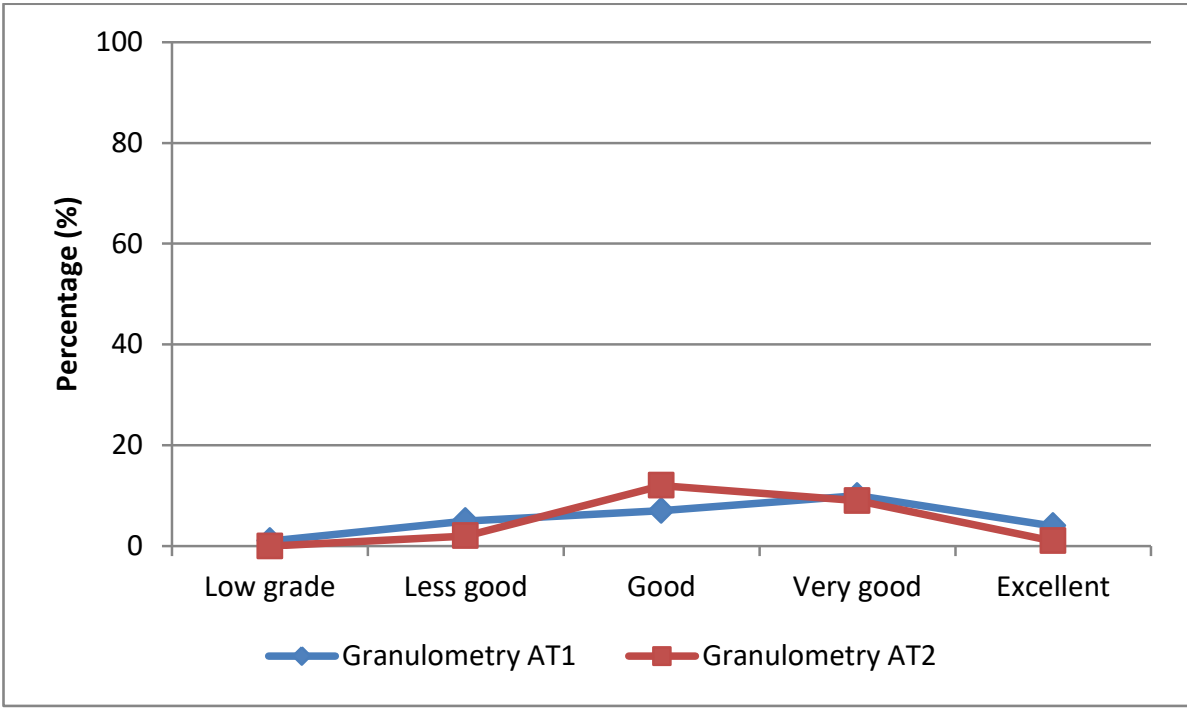

Figure 6. Tasting panel results of granulometry 


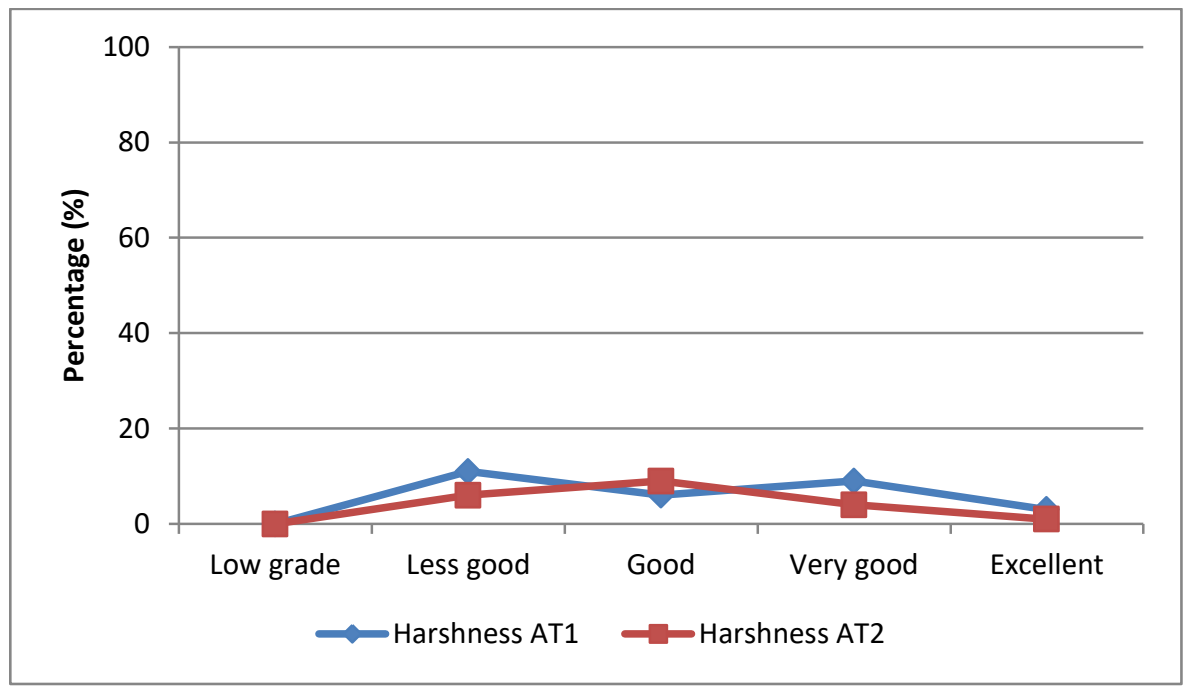

Figure 7. Tasting panel results of harshness

Table 1. Good manufacturing practices (GMP) and good hygiene practices (GHP) for attiéké producers

\begin{tabular}{|c|c|c|c|c|}
\hline Subjects & Requirements & Findings & Assessments & Recommendations \\
\hline $\begin{array}{l}\text { Personal items } \\
\text { (jewelery, } \\
\text { watches, rings); } \\
\text { nails, polishing, } \\
\text { smoking, drinking } \\
\text { and eating during } \\
\text { the service. }\end{array}$ & $\begin{array}{c}\text { People involved in peeling, grinding, } \\
\text { sieving cassava and dough should } \\
\text { have short, clean and healthy finger } \\
\text { nails. } \\
\text { Jewelry and watches are not } \\
\text { allowed. During the service you } \\
\text { must not smoke, eat or drink }\end{array}$ & $\begin{array}{l}\text { In accordance with } \\
\text { the requirements }\end{array}$ & Convenable & No recommendations \\
\hline Wounds & $\begin{array}{c}\text { In the event of an accident at work, } \\
\text { such as knife wounds during peeling, } \\
\text { a bandage must be made. }\end{array}$ & $\begin{array}{l}\text { In accordance with } \\
\text { the requirements } \\
\text { (within the unit we } \\
\text { have a bandage kit) }\end{array}$ & Convenable & No recommendations \\
\hline Hand washing & $\begin{array}{l}\text { Staff should wash their hands at the } \\
\text { beginning of each operation, after } \\
\text { using toilet, after having lathered ... }\end{array}$ & $\begin{array}{l}\text { Not in accordance } \\
\text { with the } \\
\text { requirements }\end{array}$ & Not convenable & $\begin{array}{l}\text { Install sinks (hands } \\
\text { washing system) } \\
\text { where it's necessar } \\
\text { and make sure that it } \\
\text { normally operates }\end{array}$ \\
\hline Diseases & $\begin{array}{c}\text { Any sick or infected person must } \\
\text { take leave of the processing } \\
\text { operations. }\end{array}$ & $\begin{array}{l}\text { In accordance with } \\
\text { the requirements }\end{array}$ & Convenable & No recommendations \\
\hline Medical visits & $\begin{array}{c}\text { Before hiring and at least once a } \\
\text { quarter, medical visits must be } \\
\text { organized }\end{array}$ & $\begin{array}{l}\text { Not in accordance } \\
\text { with the } \\
\text { requirements }\end{array}$ & Not convenable & $\begin{array}{l}\text { Organization of } \\
\text { quarterly medical } \\
\text { check-ups and health } \\
\text { record requirements } \\
\text { for hiring. }\end{array}$ \\
\hline Staff work clothes & $\begin{array}{l}\text { The staff must have different } \\
\text { colored work clothes (one for } \\
\text { handling in the clean area and the } \\
\text { other for the dirty area). He must } \\
\text { have at their disposal puffers, hair- } \\
\text { covers, boots. }\end{array}$ & $\begin{array}{l}\text { In accordance with } \\
\text { the requirements }\end{array}$ & Convenable & No recommendations \\
\hline Locker rooms & $\begin{array}{l}\text { Staff must get rid of their city } \\
\text { outfits, their private belongings and } \\
\text { put on cloakroom work clothes. }\end{array}$ & $\begin{array}{l}\text { Not in accordance } \\
\text { with the } \\
\text { requirements }\end{array}$ & Not convenable & $\begin{array}{l}\text { Have cloakrooms for } \\
\text { this purpose and } \\
\text { different cabinets for } \\
\text { dirty outfits, clean for } \\
\text { production and outfits. }\end{array}$ \\
\hline $\begin{array}{l}\text { Workers staff } \\
\text { training }\end{array}$ & $\begin{array}{l}\text { All staff must receive appropriate } \\
\text { training prior to the start of } \\
\text { activities and have adequate } \\
\text { supervision during the work. }\end{array}$ & $\begin{array}{l}\text { In accordance with } \\
\text { the requirements }\end{array}$ & Convenable & No recommendations \\
\hline
\end{tabular}


Table 2. Good manufacturing practices (GMP) and good hygiene practices (GHP) in food environment

\begin{tabular}{|c|c|c|c|c|}
\hline Subjects & Requirements & Findings & Assessments & Recommendations \\
\hline General plan & $\begin{array}{l}\text { Respect for the forward } \\
\text { march of the product and } \\
\text { workers staff }\end{array}$ & $\begin{array}{l}\text { Not in accordance } \\
\text { with the } \\
\text { requirements }\end{array}$ & Not convenable & $\begin{array}{l}\text { Separation of dirty and } \\
\text { clean places }\end{array}$ \\
\hline $\begin{array}{c}\text { Construction and } \\
\text { materials }\end{array}$ & $\begin{array}{l}\text { Wall and floor coverings } \\
\text { smooth, clear, washable, } \\
\text { resistant. Sufficient } \\
\text { lighting; roof ceiling, } \\
\text { windows with fine grates, } \\
\text { doors with smooth } \\
\text { surfaces }\end{array}$ & $\begin{array}{l}\text { Not in accordance } \\
\text { with the } \\
\text { requirements }\end{array}$ & Not convenable & $\begin{array}{l}\text { Apply the requirements } \\
\text { using accommodated } \\
\text { buildings }\end{array}$ \\
\hline $\begin{array}{l}\text { The entrance and exit } \\
\text { doors }\end{array}$ & $\begin{array}{l}\text { A door for the entrance } \\
\text { of the cassava, a door for } \\
\text { the entrance of the } \\
\text { workers staff, a door for } \\
\text { the exit of the finished } \\
\text { product (the atiéké) }\end{array}$ & $\begin{array}{l}\text { Not in accordance } \\
\text { with the } \\
\text { requirements }\end{array}$ & Not convenable & $\begin{array}{l}\text { Application of walking } \\
\text { forward }\end{array}$ \\
\hline Toilets & $\begin{array}{c}\text { Toilets can never be } \\
\text { directly accessible from } \\
\text { the packaging or storage } \\
\text { area }\end{array}$ & $\begin{array}{l}\text { In accordance } \\
\text { with the } \\
\text { requirements }\end{array}$ & Convenable & No recommendations \\
\hline $\begin{array}{c}\text { Establishment of a pest } \\
\text { control plan }\end{array}$ & $\begin{array}{l}\text { Pest control plan, insect } \\
\text { control plan in the } \\
\text { buildings (window wire- } \\
\text { netting, smooth doors) } \\
\text { including the } \\
\text { surroundings. } \\
\text { Registration form for } \\
\text { periodic control } \\
\text { operations. }\end{array}$ & $\begin{array}{l}\text { Not in accordance } \\
\text { with the } \\
\text { requirements }\end{array}$ & Not convenable & $\begin{array}{c}\text { Develop a pest control plan } \\
\text { and a record of periodic } \\
\text { operations. }\end{array}$ \\
\hline
\end{tabular}

Table 3. Characteristics of analyzed attiéké

\begin{tabular}{|c|c|c|}
\hline \multirow{2}{*}{ Characteristics } & \multicolumn{2}{|c|}{ Samples } \\
\cline { 2 - 3 } & AT1 & AT2 \\
\hline $\mathrm{pH}$ & $3.6 \pm 0.08$. & $3.6 \pm 0.08$. \\
\hline Acidity & $0.85 \pm 0.02$ & $1.9 \pm 0.07$ \\
\hline Humidity & $49.13 \pm 0.02$ & $53.5 \pm 0.05$ \\
\hline Ash content & $0.82 \pm 0.05$ & $0.82 \pm 0.05$ \\
\hline \multicolumn{2}{|r|}{ Legend : AT1 = Attiéké 1, AT2 = Attiéké 2} \\
\hline
\end{tabular}

Table 4. Microbiologycal quality of analyzed Attiéké

\begin{tabular}{|c|c|c|}
\hline \multirow{2}{*}{$\begin{array}{c}\text { Microbiologycal } \\
\text { parameters }\end{array}$} & AT1 & AT2 \\
\cline { 2 - 3 } & $4.52 .10^{4} \mathrm{cfu} / \mathrm{g}$ & $3.73 .10^{4} \mathrm{cfu} / \mathrm{g}$ \\
\hline Total Aerobic Mesophil Flora & $\leq 15 \mathrm{cfu} / \mathrm{g}$ & $\leq 15 \mathrm{cfu} / \mathrm{g}$ \\
\hline Total coliforms & $0 \mathrm{cfu} / \mathrm{g}$ & $0 \mathrm{cfu} / \mathrm{g}$ \\
\hline Fecal coliforms & $4.2 .10^{3} \mathrm{cfu} / \mathrm{g}$ & $3.1 .10^{3} \mathrm{cfu} / \mathrm{g}$ \\
\hline Yeasts and Molds & Legend : AT1 = Attiéké 1, AT2 = Attiéké 2 \\
\hline
\end{tabular}

\section{Discussion}

For acidity and $\mathrm{pH}$, our results are in agreement with those of (Guira, 2013) which found values between $0.92 \pm$ 0.05 and $4.08 \pm 0.57$ for acidity and 3.7 to $4.5 \pm 0,01$ for $\mathrm{pH}$. Our results are also consistent with the results of Sotomey et al. (2001) which after analysis of the Beninese diet had an average $\mathrm{pH}$ of $5.03 \pm 0.24$ and an acidity of $2.12 \pm 0,21$. Guira et al. (2016) found a pH between 3.48 and 6.30 with an acidity of between $1.8 \%$ and $12.4 \%$ which is consistent with our results. CODINORM standards require a pH between 4 and 5 (CODINORM, 2006).

The washing and soaking of the dough would have a key role in the adjustment of the acidity. It can be controlled by tasting the dough before pressing. If the acidity is not suitable, the dough can be washed once more.

In this study, the moister content of attiéké samples varied from $49.13 \pm 0.02$ to $53.5 \pm 0.05$ per $100 \mathrm{~g}$ of attiéké. These results are in agreement with that found by (Guira, 2013) which ranged between 50.19 and $55.12 \pm$ 
0.17. Sahore and Nemlin (2010) found a moister content of $48 \pm 0.1$ for that of cassava from the bitter variety and55.21 \pm 0.03 for attiéké from cassava of the sweet variety. Standards CODINORM recommends moisture content between 45 and 55\% (CODINORM, 2006).

This rate should not be too high because it will promote the proliferation of microbial flora. It can be controlled during the press, the pre-drying, the cooking and it will also allow the attiéké conservation long enough. Our analysis showed a total ash content which is in agreement with those reported by Guira (2013) which were between 0.14 and $0.78 \pm 0.02$. Sotomey et al. (2001) also reported ash content of $0.68 \pm 0.09 \%$. According to CODINORM (2006) which requires less than $1.4 \%$ dry matter as mineral salts values, our result $(0.82 \%)$ reflects the quality of our product. The ash content can also vary as a result of good hygienic and manufacturing practices during the different processes.

Otherwise, this study showed a total mesophilic flora level varying between $4.52 .10^{4}$ and $3.73 .10^{4} \mathrm{cfu} / \mathrm{g}$. This result is framed by those found by Sotomey et al. (2001) who found a variant flora between $3.4 .10^{3}$ to $2.6 .10^{7}$ $\mathrm{cfu} / \mathrm{g}$. Our results confirm those of Guira et al. (2016) who reported a total flora population of $5.11 \mathrm{log}$ at $9.3 \mathrm{log}$ $\mathrm{cfu} / \mathrm{g}$. CODINORM standards require a rate $\leq$ at $10^{6} \mathrm{cfu} / \mathrm{g}$ (CODINORM, 2006).

For yeasts and molds we had a population respectively $3.1 .10^{3}$ and $4.2 .10^{3} \mathrm{cfu} / \mathrm{g}$ for the $100 \mathrm{~g}$ of attiéké analyzed. These results are consistent with the results of previous work conducted by Sotomey et al. (2001) who found $2.6 .10^{3} \pm 1.1 .10^{3} \mathrm{cfu} / \mathrm{g}$. CODINORM standards (2006) recommend a rate between $8.10^{4}$ and $2.10^{8} \mathrm{ufc} / \mathrm{g}$. These yeasts and molds decrease considerably in the fresh diet and this reduction of microbial populations in the diet may be due to the effect of heat during cooking.

The total coliforms of our samples were $\leq 15 \mathrm{cfu} / \mathrm{g}$ and faecal coliforms were not found. This result might be due to the respect of Good Manufacturing practices (GMP) and Good Hygiene Practices (GHP). Indeed, Barro et al. (2006) showed the need for more respect of GMP and GHP in order to reduce street foods contamination. Our finding about faecal coliform is perfectly in agreement with the requirements of CODINORM and reflects the state of health quality of the analyzed attiéké. This quality can decrease with the presence of coliforms when the moisture content of attiéké increases, thus constituting a risk for the consumers.

\section{Conclusion}

Our findings show the importance of Good Manufacturing practices (GMP) and Good Hygiene Practices (GHP) to stabilize attiéké's production and also to reduce its contamination. In fact, special attention should be given to the following: transmission of fecal germs; handling of attiéké after cooking and equipments used for serving; and hand washing and environmental hygiene. Action along these lines can be expected to improve the safety of attiéké and protect consumers. Otherwises, it seems that food safety education is a critical part of the overall strategy to reduce the incidence of food borne illness and complements regulatory and other activities. Meeting the huge challenge of food safety in the 21st century will require the application of new methods to identify, monitor and assess food borne hazards. Both traditional and new technologies for assuring food safety should be improved and fully exploited.

\section{Acknowledgements}

The authors thank the "Laboratoire du Lycée Professionnel Régional Nazi BONI (LLPRNB) de Dédougou" and the "Projet sur la Résilience des Populations pauvres et très pauvres, et sécurité alimentaire dans la boucle du Mouhoun (REPAM)/Groupe de Recherche et d'Échange Technologique (GRET), for technical support. We also thank the attiéké's producers of Dédougou for their honest cooperation.

\section{References}

[1]. Padmaja G., and Steinkraus K.H. (1995), Cyanide Detoxification in Cassava for Food and Feed Uses. Critical Reviews in Food Science and Nutrition, 35, 299-329. http://dx.doi.org/10.1080/10408399509527703

[2]. Diancoumba D. (2008), Diagnostic actualisé de la filière manioc pour une analyse de chaines de valeur (CVA). PDA, p. 25.

[3]. Guira F., Kabore D., Sawadogo-Lingani H., and Savadogo A. (2016), Hygienic Quality and Nutritional Value of Attiéké from Local and Imported Cassava Dough Produced with Different Traditional Starters in Burkina Faso. Food and Nutrition Sciences, 7, 555-565.

[4]. W.H.O. (Worl Health Organization) (2002a), WHO globalstrategy for food safety safer food for better health. World Health Organization, Geneva Sitzerland ISBN 924 154574 7. http://www.who.int/foodsafety/ publications/ genarl/en/strategy-en.pdf

[5]. W.H.O. (Worl Health Organization) (2002b), Foof safety and foodborne illness. Fact Sheet, nE237, 7p.

[6]. Barro N., Nikiéma P., Ouattara C.A.T., and Traoré A.S. (2002), Evaluation de l'hygiène et de la qualité microbiologique de quelques aliments rue et les caractéristiques des consommateurs dans les villes de Ouagadougou et de Bobo-Dioulasso (Burkina Faso). Rev. Sci. Tec. Sci. Santé, 25: 7-21.

[7]. Mensah P., Yeboah-Manu D., Owusu-Darko K., and Ablorde A. (2002), Street foods in Accra, Ghana: how safe are they?.Bull W. H. O., 80: 546-554.

[8]. Bassolé I.H.N. (2009), Evaluation des acquis des formations en Bonnes pratiques d'Hygiène (BPH) au profit des transformations de manioc en attiéké, session de. s. I. PDA, 2011, 47.

[9]. ONUDI (Organisation des Nations Unies pour le Développement Industriel) (2005), Les petites et moyennes entreprises alimentaires à l'heure de la qualité. Expériences et études de cas au Burkina Faso, Vienne, 164 .

[10]. AOAC International (2000), AOAC Official Method 991.26 (2000). In: Horwitz, W., Official Methods of Analysis of 
AOAC International, AOAC International, Gaithersburg, Maryland.

[11]. ISO-6887 (1999), 1. Microbiologie des aliments-Préparation des échantillons, de la suspension mère et des dilutions décimales en vue de l'examen microbiologique. Partie 1: Règles générales pour la préparation de la suspension mère et des dilutions décimales. p. 5 .

[12]. ISO-7954 (1988), Directives générales pour le dénombrement des levures et moisissures, techniques par comptage des colonies à $25^{\circ} \mathrm{C}$. p. 4.

[13].ISO-15214 (1998), Microbiology of Food and Animal Feeding Stuffs-Horizontal Method for the Enumeration of Mesophilic Lactic Acid Bacteria-Colony Count Technique at $30^{\circ} \mathrm{C}$. p. 5.

[14]. CODINORM (2006), Attiéké-spécifications. NI4511 Côte d'Ivoire, Norme.
[15]. Guira F. (2013), Evaluation des valeurs nutritive et sanitaire d'attiéké issu de différentes pâtes de manioc importées ou produites localement à partir de différents ferments. p. 79.

[16].Sahoré, D.A., and Nemlin, G.J. (2010), Effect of Technological Treatments on Cassava (Manihot esculenta Crantz). Food and Nutrition Sciences, 1, 19-23. http://dx.doi.org/10.4236/fns.2010.11004

[17]. Sotomey, M., and Eric-Alain, D. (2001), Innovation Diffision de Produits Alimentaires en Afrique: I'attiéké au Bénin. CIRAD, 98.

[18]. Barro N., Bello A.R., Savadogo A., Ouattara C. A.T., Ilboudo A.J., and Traoré A.S. (2006), Hygienic status assessment of dish washing waters, utensils, hands and pieces of money from street food processing sites in Ouagadougou (Burkina Faso). African Journal of Biotechnology, 5 (11), 1107-1112. 